\title{
KEHIDUPAN SOSIAL WARGA BELAJAR SATUAN PENDIDIKAN NON FORMAL SANGGAR KEGIATAN BELAJAR KABUPATEN BANJAR
}

\author{
Oleh: \\ Desita Handayani \\ Email: handayanidesyta@gmail.com \\ Progam Studi Magister Pendidikan IPS \\ Pascasarjana Universitas Lambung Mangkurat Banjarmasin
}

\begin{abstract}
Abstrak
Pendidikan tidak hanya diberikan kepada mereka yang berada di sekolah saja. Satuan Pendidikan Non Formal Sanggar Kegiatan Belajar Kabupaten Banjar menyediakan tempat bagi semua masyarakat yang ingin terus menimba ilmu tanpa harus khawatir dengan kehidupan sosial mereka. Kehidupan bermasayarakat yang dijalani oleh semua warga belajar tidak terlepas dari adanya pendidikan IPS yang mereka pelajari di SPNF SKB Kabupaten Banjar. Dengan adanya proses pembelajaran ini mereka bisa mengimplementasikan pendidikan IPS ke dalam kehidupan sosial. Tujuan penelitian ini adalah untuk mendeskripsikan kehidupan sosial warga belajar SPNF SKB Kabupaten Banjar dengan melihat implementasi yang mereka dapat dalam pendidikan IPS. Metode yang digunakan dalam penelitian ini adalah metode kualitatif deskriptif. Data dikumpulkan dengan proses observasi, wawancara dan dokumentasi. Menganalisis data dengan penyajian data, reduksi data serta verifikasi data. Sedangkan untuk menguji keabsahan data dilakukan dengan cara trianggulasi tempat, teknik, dan sumber. Hasil dari penelitian ini adalh gambaran kehidupan sosial warga belajar SPNF SKB Kabupaten Banjar baik saat berada di sekolah maupun di lingkungan keluarga. Kehidupan sosial warga belajar juga terdapat implementasi pendidikan IPS yang diperoleh dari proses hasil belajar mengajar. Proses yang berlangsung selama kegiatan mereka sehari-hari mampu menunjukkan adanya peran pendidikan IPS sebagai dasar bermasayarakat.
\end{abstract}

Kata kunci: Kehidupan Sosial, Pendidikan IPS, Satuan Pendidikan Non Formal

\begin{abstract}
Education is not only given to those who are in school. The Non-Formal Education Unit of the Banjar Regency Learning Activity Studio provides a place for all people who wish to continue to gain knowledge without having to worry about their social life. The social life that all learning citizens live is inseparable from the social studies education they learn at SPNF SKB Banjar Regency. With this learning process they can implement social studies education in their social life. The purpose of this study was to describe the social life of the learning citizens of SPNF SKB Banjar Regency by looking at the implementation they got in social studies education. The method used in this research is descriptive qualitative method. Data were collected by a process of observation, interviews and documentation. Analyze data by presenting data, data reduction and data verification. Meanwhile, to test the validity of the data is done by triangulation of places, techniques, and sources. The result of this research is a description of the social life of the learning citizens of SPNF SKB Banjar Regency both at school and in the family environment. The social life of the learning community also includes the implementation of social studies education obtained from the teaching and learning process. The processes that take place during their daily activities are able to show the role of social studies education as the basis of society.
\end{abstract}

Keywords: Social Life, Social Studies Education, Non-Formal Education Unit 


\section{PENDAHULUAN}

Dewasa ini kita mengetahui dengan pasti bahwa dunia semakin bertambah maju dan berkembang. Berbagai bidang kehidupan juga satupersatu mengikuti arus perubahan yang terjadi. Perkembangan yang mendunia ini juga masuk ke dalam bidang pendidikan. Dalam bidang pendidikan sudah semestinya untuk selalu melakukan pembaharuan untuk mencapai tujuan pendidikan yang sebenar-benarnya. Hal ini tentunya akan membantu pendidikan agar bisa menjangkau semua kalangan. Dalam standar pendidikan nasional hal ini telah diatur mengenai lingkup, fungsi dan tujuan pendidikan itu sendiri

Peraturan Pemerintah No. 19 tahun 2005 tentang Standar Nasional Pendidikan Indonesia dalam Bab 2 Pasal 2 Ayat 3 dengan jelas dicantumkan bahwa Standar Nasional Pendidikan disempurnakan secara terencana, terarah, dan berkelanjutan sesuai dengan tuntutan perubahan kehidupan lokal, nasional dan global. Dengan sangat jelas pula pada pasal 4 bahwa Standar Nasional Pendidikan bertujuan menjamin mutu pendidikan nasional dalam rangka mencerdaskan kehidupan bangsa dan membentuk watak serta peradaban nasional yang bermutu. Pada dasarnya, pemerintah telah membuat peraturan dengan sangat memperhatikan setiap jangkauan yang akan dicapai oleh pendidikan. Tujuan pendidikan juga tidak hanya sampai kepada mencerdaskan kehidupan bangsa yang jelas kita tahu hal ini juga sangat jelas dalam pembukaan Undang Undang Dasar 1945. Tujuan dari pendidikan nasional yang lebih jauh lagi adalah membentuk watak serta peradaban bangsa yang bermatabat.

Dalam langkah-langkah yang akan diambil untuk mencapai tujuan tersebut tentunya tidak bisa hanya dengan menyamaratakan semua standar pendidikan. Hanya dengan melihat, kita tau bahwa Indonesia ini terdiri dari ratusan pulau yang dari Sabang sampai dengan Meraukenya memiliki perbedaan baik dalam segi keadaan geografis, keadaan sosial serta historis dan kebudayaannya masing-masing. Berkaca dengan hal ini bagaimana bisa pendidikan menjadi sama, padahal keadaan dan kebutuhannya saja berbeda-beda. Melihat hal ini juga sangat perlu ada yang dinamakan pendidikan lokal sesuai yang tercantum di pasal 2 ayat 3 sebelumnya.

Pendidikan di Indonesia sendiri tidak hanya sebatas pelaksanaan pendidikan formal. Pendidikan Masyarakat atau Dikmas juga menjadi salah satu aset pemerintah untuk mencapai tujuan pendidikan. Dengan adanya pendidikan masyarakat, warga Negara Indonesia yang memiliki keterbatasan untuk belajar di sekolah formal tentunya memiliki kesempatan untuk mendapatkan hak yang sama dalam memperoleh pendidikan. Pendidikan non formal yang tersebar di seluruh wilayah Indonesia memberikan kesempatan kepada seluruh masyarakat untuk terus belajar, baik yang masih dalam usia sekolah maupun yang sudah melewati usia sekolah seharusnya. Dengan berbagai macam latar belakang sosial, 
ekonomi serta budaya, tidak ada hal yang tidak mungkin untuk belajar.

Kehidupan para warga belajar di satuan pendidikan non formal ini berbeda dengan kehidupan seharihari para siswa di sekolah formal. Walaupun pembelajaran yang dilakukan oleh para pendidik maupun tutor sudah dimaksimalkan agar bisa menyamai pembelajaran yang dilaksanakan oleh sekolah formal, hal ini menjadi perhatian bagi peneliti terkhusus pada kehidupan sosial sehari-hari mereka. Bagaimana penerapan ilmu sosial yang mereka terima dan yang mereka implementasikan di rumah menjadi fokus utama dalam penelitiam ini. Dalam permasalahan seperti ini peneliti ingin melihat lebih jauh lagi mengenai nilai pembelajaran ilmu sosial yang mereka terima dengan kehidupan mereka sehari-hari pada pendidikan non formal khususnya pada pendidikan warga belajar Paket $B$ dan C di SPNF SKB Kabupaten Banjar.

Kehidupan sosial seperti namanya yakni kehidupan bersosial atau kehidupan bermasyarakat. Selain di dalam keluarga, sekolah merupakan tempat para warga belajar bersosialisasi. Di dalam pembelajaran pun ada ilmu sosial yang mengajarkan tentang bersosialisai. Satuan Pendidikan Non Formal Kab. Banjar menyediakan kesetaraan setara paket B dan C. pembelajaran sosial yang didapatkan di Paket B adalah pelajaran IPS, sedangkan di Paket C ada sosiologi, sejarah, ekonomi, geografi yang semuanya mengajarkan tentang hidup di dalam masyarakat. Kehidupan sosial ini berjalan baik saat warga belajar berada di lingkungan Sanggar Kegiatan Belajar (SKB) maupun saat berada di rumah mereka masingmasing. Bagaimana setiap warga belajar saling berkomunikasi dan menyikapi sesuatu hal yang terjadi di antara mereka. Bagaimana mereka memecahkan sebuah masalah dan mendapatkan solusi sebagaimana yang telah di ajarkan sebelumnya di kelas serta bagaimana mereka menyikapi perbedaan saat berada di lingkungan rumah dan lingkungan SKB.

Kehidupan sosial yang dikemukakan oleh Anggraeni dan Hendrizal (2018) adalah kehidupan yang di dalamnya terdapat unsurunsur sosial/kemasyarakatan. Sebuah kehidupan disebut kehidupan sosial jika di sana ada interaksi antara satu individu dengan individu lainnya. Hal ini akan semakin berkembanga dengan adanya komunikasi di antara mereka satu sama lainnya. Zaman yang serba-serbinya tidak jauh dengan teknologi, komunikasi di antara individu juga tidak bisa diartikan sempit. Komunikasi yang dalam sosiologi merupakan salah satu syarat interaksi sosial kini bisa dilakukan dengan banyak cara.

Rochgiyanti (Ersis, 2013:135) aspek terpenting dalam komunikasi dalam komunikasi adalah ketika seseorang memberikan penafsiran terhadap perilaku dan perasaan yang ingin disampaikan kepada seseorang. Penafsiran yang demikian akan ditangkap secara berbeda oleh individu yang lainnya. Karena itu 
pentingnya menyamakan maksud dan tujuan komunikasi saat berinteraksi. Perbedaan penafsiran ini terjadi karena dalam prosesnya seseorang tidak dapat menangkap maksud salah satunya. Proses penafsiran yang tidak sempurna inilah yang menjadi kendala dalam komunikasi.

Dalam pengembangan komunikasi, teknologi sangat cepat merubah pola dan jalan manusia untuk saling berkomunikasi satu sama lain. Hasan (Anggraeni dan Hendrizal, 2018:70) mengemukakan teknologi komunikasi memungkinkan terjadinya transformasi secara luas dalam kehidupan manusia. Transformasi tersebut telah memunculkan perubahan dalam berbagai hal pola hubungan antarmanusia (patterns of human communication), yang pada hakikatnya adalah interaksi antar pribadi. Namun, dalam pembahasan kehidupan sosial bukan hanya sebatas interaksi dan komunikasi saja. Sebelumnya, warga belajar yang saling bersosialisasi satu sama lain di SKB maupun pada saat mereka di rumah telah mendapatkan pembelajaran apa itu bermasyarakat. Sehingga baik secara langsung maupun tidak langsung apa yang mereka dapatkan saat belajar akan tercermin ke dalam kehidupan sosial sehari-hari.

Pembelajaran awal yang memberikan mereka pandangan mengenai kehidupan sosial adalah pendidikan IPS. Pendidikan IPS yang mengajarkan kehidupan sosial bermasyarakat, mengajarkan nilai dan norma yang ada serta memperkenalkan bagaimana karakteristik kehidupan bermasyarakat, baik secara umum, maupun lokalitas daerah. Dari pendidikan IPS ini warga belajar memperluas pandangan mereka sendiri terhadap apa yang terjadi di sekitar mereka. Bagi Heri (Ersis 2015:191) pendidikan IPS diharapkan mampu menjadi garda terdepan dalam upaya menumbuhkan pemahaman multikulturalisme dan mengembangkan nilai-nilai budaya lokal menjadi unggulan lokal. Harapan yang demikian tentunya akan tercipta dengan perkembangan para peserta didik atau warga belajar yang berhasil mengimplementasikan pendidikan IPS ke dalam kehidupan sosial mereka sehari-hari.

\section{METODE}

\begin{tabular}{lcr}
\multicolumn{2}{c}{ Penelitian ini } & dilakukan \\
dengan & menggunakan & metode \\
penelitian & kualitatif. & Penelitian
\end{tabular}
kualitatif yang bersifat deskriptif ini sangat cocok dengan penelitian yang membahas kehidupan sosial warga belajar Satuan Pendidikan Non Formal Sanggar Kegiatan Belajar Kabupaten Banjar. Dalam penelitian ini mengamati kehidupan sosial atau kehidupan bermasyarakat warga belajar baik di lingkungan keluarga maupun lingkungan SKB dengan dasar pendidikan IPS yang telah mereka pelajari. Dalam hal ini peneliti banyak berhubungan dengan para pengeloka $\mathrm{SKb}$, Tutor Bantu mata pelajaran IPS, warga belajar, serta orang terdekat dari warga belajar sendiri. 
Penelitian ini dilaksanakan di Satuan Pendidikan Non Formal Sanggar Kegiatan Belajar Kabupaten Banjar yang bertempat di Jalan Chandra Kirana Rt 05, Desa Indrasari, Kecamatan Martapura, Kabupaten Banjar. Waktu penelitian pada semester Ganjil di bulan Oktober hingga November 2020. Teknik pengumpulan data dilakukan melalui wawancara, observasi dan dokumentasi. Teknik analisis data menggunakan model Miles and Huberman (1985) yang dilakukan secara interaktif dimana data yang didapat jika sudah mencapai titik jenuh maka pencarian data akan dihentikan. Hal ini meliputi data reduction, display data, dan verivication. Keabsahan data diuji dengan melalui uji kredibilitas yakni perpanjangan pengamatan, meningkatkan ketekunan dan trianggulasi.

\section{HASIL}

\section{A. Gambaran Kehidupan Sosial Warga Belajar SPNF SKB Kab. Banjar}

1. Di Lingkungan SPNF SKB Kab Banjar

Di sekolah formal, sebutan untuk anak-anak yang belajar adalah siswa dan siswi, berbeda dengan yang ada di satuan pendidikan non formal. Sebutan untuk para siswa adalah warga belajar. Hal ini berbeda karena tidak semua murid di satuan non formal ini masih berusia anak sekolah. Hampir separuh dari mereka berusia di atas usia belajar. Karena itulah sebutan untuk mereka lebih tepat jika warga belajar.

Sebutan warga belajar ini juga sangat cocok untuk mereka. Terutama dalam simulasi sebuah "warga" dalam lingkungan belajar. Warga belajar yang tergabung di SPNF SKB tidak setiap hari dapat bergabung dengan teman sekelas mereka untuk mengikuti pelaksaan pembelajaran di kelas. Sebagian besar dari mereka sudah berkerja atau sedang mencari pekerjaan. Tidak hanya berisi warga belajar yang sedang berkerja, warga belajar juga kebanyakan merupakan ibu rumah tangga yang setiap hari pagi mereka diisi dengan mengurus kebutuhan dan keperluan rumah tangga terlebih dahulu seperti menyiapkan sarapan untuk anak serta suami mereka. Setelah kewajiban sebagai seorang ibu rumah tangga telah dilakukan mereka bisa mengikuti kegiatan belajar mengajar di SPNF SKB.

Walaupun kebanyakan warga belajar diisi oleh mereka yang sudah tidak lagi berada di usia sekolah, bukan berarti tidak ada lagi warga belajar yang memang berada dalam usia sekolah. Di SPNFSKB Kab Banjar, usia sekolah yang ada di sana di dominasi oleh para santri dan santriwati dari pondok pesantren. Mereka yang tidak memiliki pendidikan yang sifatnya umum di pondok pesantren memilih untuk membagi waktu mereka dengan sebaik mungkin dan 
mendaftarkan diri sebagai warga belajar di SPNF SKB. Hal ini akan sangat membantu mereka untuk mendapatkan ijazah sekolah formal yang tidak mereka dapatkan di pondok pesantren. Dengan demikian selepasnya mereka dari jenjang pendidikan yang ada di pondok pesantren mereka juga telah menyelesaikan pendidikan mereka yang setara dengan SMP hingga SMA dengan waktu yang bersamaan.

Selain warga belajar yang telah disebutkan, masih ada satu dan dua orang yang memang tidak masuk ke skolah formal dan mendaftar sebagai warga belajar karena mereka tidak tahan dengan sistem belajar mengajar di sekolah formal yang terkesan ketat aturan dan penuh dengan jadwal belajara yang juga padat. Di tambah dengan tugas-tugas serta tambahan latiahan lain yang tidak sanggup mereka ikuti. Dengan alas an ini mereka tidak lagi bersekolah di sekolah formal dan memilih menjadi warga belajar di SPNF SKB Kab Banjar.

Kehidupan sosial warga belajar di lingkungan SPNF SKB lebih terlihat ketika mereka mengikuti kelas khusus yang berupa keterampilanketerampilan terpilih. Keterampilan yang disediakan oleh SPNF SKB.

Kelas keterampilan yang disediakan di SPNF SKB Kab Banjar ada tiga, yakni menjahit, tata boga, dan keterampilan komputer. Saat kelas keterampilan menjahit berjalan, warga belajar yang di mendominasi mengisi kelasnya adalah warga belajar perempuan, baik yang sudah menikah maupuun yang masih sendiri. Walaupun pengajar atau tutor bantu keterampilan menjahit adalah seorang laki-laki, warga belajar mengikuti kelas dengan antusias. Setiap kegiatan menjahit yang terkesan bisa dikerjakan sendiri ini tidak menghalangi mereka untuk saling bekerja sama. Dalam kelas keterampilan menjahit, mereka tidak sungkan untuk bertanya dengan sesama warga belajar. Di dalam kelas yang kebanyakan berisi anak perempuan itu tidak semuanya seumuraan. Artinya, di dalam kelas mereka berinteraksi dengan orang yang lebih tua maupun yang lebih muda dari mereka. Saat kelas berlangsung mereka bersikap seakan mereka seumuran dan tidak ada kata sungkan atau malu lagi. Saling bekerja sama, tolong menolong dan bercanda pun mereka lakukan tanpa ada perselisihan di antara mereka.

Kelas keterampilan yang selanjutnya yaitu kelas keterampilan komputer. Tidak seperti kelas menjahit, kelas komputer terlihat sama rata diisi oleh warga belajar laki-laki maupun perempuan. Walaupun jika dilihat keseluruhan masih diisi oleh warga belajar denan usia sekolah. Kelas keterampilan komputer sanagt dianjurkan diikuti oleh seluruh warga belajar. 
Bagi satuan pendidikan non formal, keterampilan komputer saat ini setidaknya sudah menjadi dasar keterampilan yang seharusnya dimiliki oleh setiap orang. Perkembangan terknologi yang setiap waktu kian maju saja, tidak bisa diindahkan begitu saja. Karena itulah warga belajar juga $\mathrm{t}=$ dengan senang hati mengikuti keterampilan komputer ini demi mereka sendiri nanti.

Kelas keterampilan komputer diampu oleh tutor berpengalaman yang membuat kelas keterampilan juga bisa semakin fokus dan terarah dengan baik. Keterampilan komputer dimulai dari pengenalan dasar perangkat dan pengenalan aplikasi dasar yang biasanya digunakan. Setelah itu ada lanjutan-lanjutan pembelajaran yang juga membutuhkan ketekunan mereka sendiri. Setelah kelas keterampilan berakhir, barulah warga belajar bisa saling bercanda lagi. Interaksi yang dilakukan dalam kelas biasanya berupa interaksi formal saat salah satu diantara mereka saling bertanya apakah yang dilakukannya itu sudah benar atau belum. Kebanyakan dari warga belajar laki-laki lebih tertarik untuk membahas masalah game yang bisa mereka operasikan lewat komputer. Tapi tidak jarang mereka juga menanyakan pekerjaan apa yang kiranya bisa mereka lakukan engan menyertakan surat keterampilan komputer ini.
Keterampilan terakhir yaitu tata boga. Dalam menunjang berhasilnya keterampilan ini, SPNF SKB mengajukan beberapa alat tata boga yang sangat membantu dalam proses keterampilan ini seperti mixer, oven, dan alat-alat kecil lain yang biasanya hanya ada di toko kue. Keterampilan yang juga di dominasi oleh warga belajar perempuan ini sangat membantu mereka dalam mencoba berbagai resep dan diaplikasikan lagi di rumah mereka sendiri. Saat di kelas keterampilan tata boga mereka mencoba berbagai resep dan jenis masakan dan saling berbagi pendapat dengan tutor yang mengajar. Setelah mereka berhasil, biasnaya akan ada celebration dengan menggunakan olahan mereka yang berhasil tadi sebagai sajian utamanya. Tidak lupa mereka juga membagikan hasil yang mereka dapat ke para tutor dan pengelola SPNF SKB. Kebanyakan dari mereka yang sudah lama mengikuti keterampilan tata boga ini membuat wirausaha kecil-kecilan sendiri. Ada yang berjualalan kue, masakan jadi untuk makan siang dan sebagainya. Tidak jarang mereka mengembangkan penjualan mereka dengan berjualan secara online.

Dalam keadaan pandemi covid 19 proses belajar dan pembelajaran yang biasanya dilakukan secara tutorial dan tatap muka dengan warga menjadi beralih. Pembelajaran secara 
daring juga diterapkan oleh SPNF SKB sesuai dengan aturan yang diminta oleh pemerintah demi mengurangi penyebaran virus. Walaupun demikian bukan berarti tidak ada sama sekali interaksi yang terjadi antara warga belajar dengan tutor.

Saat pembelajaran berlangsung, tidak semua warga belajar mampu untuk memahami dan menyelesaikan apa yang telah diajarkan oleh para tutor. Untuk kendala yang seperti demikian, kepala sekolah SPNF SKB memberikan fleksibelitas aturan yang dapat membantu mereka. Mereka sangat diperbolehkan untuk datang ke sekolah dan bertanya tentang semua yang tidak mereka mengeti dan tugas yang mereka kurang pahami.

Satu kelas dari warga belajar biasanya hanya berisi 10-15 orang yang mana pada saat keadaan normal pun mereka tidak semuanya bisa hadir. Akan tetapi saat pandemi ini mereka bisa dengan mudah hadir di kelas secara daring karena tidak menuntut mereka untuk datang ke sekolah. Mereka hadir di SPNF SKB hanya pada saat ujian modul, ujian tengah semester dan ujian akhir. Dan ada saat-saat mereka datang sendiri demi menuntaskan materi yang tidak mereka kuasai.

Para tutor sudah dihimbau oleh pengelola dan kepala sekolah untuk tetap berada di SPNF SKB sesuai dengan jadwal mengajar demi warga belajar. Tidak hanya masalah menuntaskan materi, masih ada beberapa dari mereka yang tempat tinggalnya kurang didukung oleh jaringan internet. Kesulitan jaringan komunikasi yang menjadi alat utama untuk belajar ini membuat mereka lebih memilih untuk langsung datang ke pada tutor yang bersangkutan untuk belajar. Biasanya mereka yang ingin datang langsung telah menghubungi tutor yang bersangkutan dan meminta izin untuk belajar secara tatap muka. Dengan begitu, para tutor mata pelajaran juga tidak terkejut dengan kedatangan mereka dan mempersiapkan terlebih dahulu apa-apa yang perlu disiapkan untuk pembelajaran secara tatap muka dengan mereka.

\section{Di Lingkungan Keluarga}

Kehidupan sosial warga belajar di lingkungan keluarga sedikit banyaknya berbeda dengan siswa siswi di sekolah formal. Warga belajar di SPNF SKB lebih banyak memilki waktunya di rumah. Di lingkungan keluarga warga belajar yang sudah berumah tangga biasanya terlihat saat mereka sendiri yang mengekspose kegiatan mereka sehari-hari di rumah dan para tutor bisa melihat hal tersebut. Tutor dan warga belajar yang saling menyimpan nomer handphone lebih memiliki banyak mengetahui kegiatan mereka sehari-hari.

Warga belajar yang sudah berumah tangga atau bahkan sudah memiliki anak lebih 
memprioritaskan kewajiban mereka dahulu di sana sebelum akhirnya mereka mengerjakan apapun yang ada di SPNF SKB. Warga belajar biasanya menyiapkan terlebih dahulu keperluan suami dan anak mereka seperti ikut membantu tugas anak sebelum menyelesaikan tugas pelajaran mereka. Ada juga warga belajar yang ternyata jenjang pendidikannya sedang berada di jenjang yang sama dengan anaknya. Sehingga mereka berdua bisa saling bantu dalam mengerjakan tugas. Hal ini baru saja diketahui oleh bebrapa tutor saat warga belajar lupa memberikan tugasnya dan mengaku sedang membantu anaknya mengerjakan tugas yang sama dengannya.

Sebelumnya pengelola telah bertanya kepada ibu dua orang yang statusnya kini menjadi warga belajar paket B itu mengapa masih ingin melanjutkan pendidikan. Ternyata saat melihat anakanaknya sekolah, belajar, dan mengerjakan tugas masih ada terbesit dihatinya untuk sekolah lagi. Dimana pada saat ia SD dlu tidak berkesempatan untuk melanjutkan pendidikannya karena faktor ekonomi dan tuntutan orang tua agar membantunya bekerja.

Kehidupan sosial lain di lingkungan keluarga seperti ini tidak hanya satu dan dua orang warga belajar saja. Dengan berbagai alas an, walaupun mereka sudah memiliki anak, tetap tidak meruntuhkan niat mereka untuk melanjutkan sekolah. Selain itu memang ada beberapa warga belajar yang juga memiliki masalah di keluarganya. Paksaan atau tekanan-tekanan yang diterimanya sebagai seorang anak berimbas kepada sekolahnya. Pada usia sekolah yang biasanya sedang seruserunya bermain kini harus ikut bekerja dan menerima keluarganya tidak seperti temantemannya. Walaupun demikian ternyata niatnya untuk sekolah tidak padam. Sedangkan untuk warga belajar yang merangkap sekolah di pesantren kehidupan sosial mereka lebih beragam seperti kebanyakan siswa dan siswi di sekolah formal.

\section{B. Implementasi Pendidikan IPS Warga Belajar SPNF SKB Kab Banjar}

Warga belajar di SPNF SKB pada dasarnya sudah mengtahui bagaimana artinya hidup bersosial atau bermasyarakat. Karena sebagain besar dari mereka sudah berada di masyarakat yang lebih besar daripada di lingkungan sekolah. Sebagian besar warga belajar perempuan misalnya. Mereka mengaku bahwa mengikuti kegiatan-kegiatan kemasyarakatan. Seperti misalnya arisan dan yasinan yang rutin seminggu sekali diadakan. Semua warga belajar yang ikut juga mengaku mengikuti kegiatan tersebut secara aktif dan terbuka. Artinya mereka juga mempersilahkan kegaiatan tersebut diadakan di rumah mereka 
juga ketika gilirannya telah sampai. Dalam kegaiatan arisana tau yasinan yang setiap seminggu sekali berlangsung ini sebenarnya tidak memerlukan banyak orang untuk menyelenggarakannya. Anggota arisan berisi kumpulan ibu-ibu komplek baik yang berkerja mau[un tidak tergabung setiap sore hari Jumat. Kegaiatan arisan yang tidak memerlukan banyak persiapan ini nyatanya saat dilaksanakan tidak demikian. Beberapa anggota arisan yang mendapatkan gilirannya kadang memanfaatkan momen tersebut untuk membuat acara tambahan seperti haul atau selamatan di keluarga mereka sehingga acara arisan menjadi besar. Untuk melaksanakannya warga belajar juga sadar bahwa mereka sebaiknya membantu tetangga mereka untuk mempersiapkan acara tersebut hal ini sudah menjadi kebiasaan bagi mereka untuk saling membantu dalam berjalannya kegiatan acara.

Selain

kegiatan

kemasyarakatan seperti arisan dan yasinan, warga belajar SPNF SKB juga mengikuti kegiatan seperti gotong royong. Di tempat tinggal para warga belajar masih terjaga kebiasaan masyarakat yang saling gotong royong. Baik untuk menyelenggarakan kegiatan besar ataupun sengaja membuat kegiatan seperti minggu bersih di lingkungan mereka. Tempat-tempat umum seperti mushola atau langgar serta lapangan bulu tangkis yang bisa digunakan oleh semua orang adalah tempat yang dibersihkan secara gotong royong. Tidak ketinggalan para warga belajar yang tidak tinggal diam ketika adanya gotong royong di sekitar rumah mereka. Tidak para laki-lakinya saja yang membantu membersihkan tempat umum seperti memperbaiki bagian-bagian yang rusak, akan tetapi peran ibu-ibu dan warga belajar perempuan sangat dibutuhkan. Bagian para perempuan ini tidak lain untuk meringankan pekerjaan beratnya yaitu menyiapkan makanan dan minuman untuk mereka yang berkerja. Tidak jarang ada salah satu tetangga mereka ynag sengaja mnyiapkan makan siang untuk mereka yang sampai akhir berkerja untuk menyelesaikannya. Kegiatan seperti gotong royong ini tidak bisa mereka lihat saja tanpa melakukan apa-apa. Biasanya warga belajar yang masih muda dan gesit mendapatkan jatah untuk membantu dibagian yang tidak bisa dikerjakan oleh tetangga mereka seperti naik ke atas genteng atau menaiki tangga yang notabenenya berbahaya.

\section{PEMBAHASAN}

\section{A. Kehidupan Sosial Warga Belajar SPNF SKB Kab. Banjar}

Kehidupan sosial yang tergambar di dalam keseharian warga belajar SPNF SKB Kab Banjar tercipta di antara mereka, pengelola, tutor, serta lingkungan keluarga. Dalam kehidupan sosial yang tidak terlepas dari orang lain, secara sadar maupun tidak sadar mereka semua telah melakukan hal tersebut di setiap harinya. Seperti yang juga Anggraeni dan Henridzal (2018) katakan bahwa sebuha kehidupan disebut kehidupan sosial jika di sana ada interaksi dan 
komunikasi yang selanjutnya akan berlanjut dengan membutuhkan antar sesamanya. Dalam penelitian ini adalah interaksi mereka di lingkungan keluarga dan lingkungan SPNF SKB.

Interaksi adalah hubungan antar individu yang membutuhkan kontak sosial dan komunikasi sebagai syaratnya. Dalam kehidupan sosial warga belajar, interaksi sosial adalah faktor utama mereka dalam menjalankan kehidupan bermasyarakat. Dalam kehidupan sosial ini sudah warga belajar sudah melakukannya sebaik yang mereka bisa. Kegiatan-kegiatan sosial di lingkungan keluarga maupun di lingkungan SPNF SKB sudah tercermin sehari-hari. Lingkungan kecil bersama sesama warga belajar baik dalam hal belajar, bantumembantu serta dalam berteman.

Kehidupan sosial warga belajar tidak selalu berada dalam konteks yang positif. Dalam prosesnya, kehidupan sosial warga belajar juga mengalami interaksi dalam konteks yang negatif. Maksudnya adalah kehidupan sosial mereka juga sewaktu-waktu mengarah kepada perselisihan anatar sesama. Walaupun hal ini jarang terjadi, warga belajar saat dalam proses belajar dan pembelajaran juga mengalami perselisihan.

Dalam perselisihan ini mereka yang menguatkan pendapat masingmasing dan berusaha menjadi yang benar. Kemudian mereka saling mencari tahu mana sebenarnya yang benar dari pendapat mereka ini sehingga perselisihan ini bisa diselesaikan secepat yang mereka bisa. Perselisihan ini juga tidak hanya terjadi di lingkungan SPNF SKB saja. Di lingkungan keluarga, adakalanya mereka merasa tidak nyaman dengan perlakukan tetangga mereka yang sebut saja salah satunya membuang sampah sembarangan dan itu mengganggu mereka. Pencarian solusi untuk perselisihan di masyarakat in biasanya lebih lama. Hal ini dikarenakan mereka memikirkan bagaimana cara penyelesaian masalah dengan tidak menyinggung perasaan satu sama lain dan saling mengerti maksud dan tujuan dari tindakan yang mereka lakukan. Dengan demikian walaupun ada perselisihan yang terjadi di antara mereka, hubungan antar keluarga, tetangga, maupun masyarakat sekitar mereka yang lain bisa tetap terjaga dengan baik.

\section{B. Implementasi Pendidikan IPS Warga Belajar SPNF SKB Kab Banjar}

Menurut Wahab (2008: 65) implementasi adalah memahami apa yang kenyataannya terjadi sesudah suata proses dinyatakan berlaku atau dirumuskan menrupakan fokus perhatian implementasi kebijkasanaan yakni kejadiankejadian dan kegiatan-kegiatan yang timbul setelah disahkannya. Implementasi pendidikan IPS oleh warga belajar sedikit banyaknya sudah terlihat pada gambaran keseharian sosial mereka. Apa yang mereka pelajari dan apa yang merekak mengerti dari pembelajaran tentang kehidupan sosial salah satunya di dapat dalam pendidikan IPS. Dalam bersosialisasi antar warga 
belajar mereka menerapkan hubungan-hubungan sosial yang menciptakan sebuah keterikatan. Interaksi yang mereka lakukan sehari hari terutama saat berada di SPNF SKB adalah sebuah implementasi dari proses pembelajaran. Pendidikan IPS adalah pendidikan yang memberikan materimateri kehidupan sosial. Adrian (Nursya'ban, 2007) juga menjelaskan bahwa pendidikan merupakan suatu usaha yang dapat menumbuh kembangkan potensi sumber daya manusia melalui suatu kegiatan yang dikenal sebagai pembelajaran, dimana dalam proses belajar mengajar terjadi interaksi sosial antara para siswa dan guru. Sesuai dengan hal tersebut pembelajaran yang berjalan dan diikuti oleh seluruh warga belajar memenuhi unsur-unsur yang ada. Dengan membuat pembelajaran seaktif dan sebisa mungkin tetap mengikuti aturan pemerintah untuk mengadakan pembelajaran secara daring tidak menyurutkan maksud dan tujuan dari pembelajaran itu sendiri.

Pendidikan yang tercipta di pedidikan non formal ini adalah pendidikan yang melihat dan mempertimbangkan kebutuhan mereka siap di masyarakat. Selain itu, dipertegas oleh Kindervatter (Widodo dan Soedjarwo, 2019) bahwa pendidikan non formal ini berkembang berdasarkan kebutuhan belajar pada manusia. Pendidikan dengan sebutan adult education, continuing education, on the job training, accelerated learning farmer or worker training, extension learning. Semua yang telah di jelaskan ini telah terangkum dalam kegiatan warga belajar sehari-hari. Saling tolong-menolong, berkerjasama, berinteraksi dengan sesama warga belajar adalah awal mulai pembelajaran pendidikan IPS warga belajar sudah diimplementasikan pada kehidupan sosial sehari-hari.

Setia (Ersis, 2013:210) pendidikan IPS yang dalam bentuk mata pelajaran IPS diberikan pada jenjang pendidikan dasar (SD dan SMP) menjadikan ilmu-ilmu sosial sebagai sumbernya. Sumber pembelajaran IPS luas dan tidak terbatas membuat para guru dan tutor agar bisa mengembangkan pendidikan IPS lebih dari apa yang ada di buku pedoman pembelajaran saja. Pendidikan IPS yang membuat mereka mengetahui bahwa kehidupan sosial yang mereka jalani sehari-hari secara biasa merupakan hasil dari proses-proses interaksi serta hubungan sosial yang terus menerus mereka lakukan. Hal ini membuat para guru dan tutor juga berhasil untuk memberikan pengertian dalam pembelajaran bahwa pendidikan IPS hadir di dalam kehidupan sosial mereka sehari-hari.

Implementasi pendidikan IPS di dalam kehidupan sosial warga belajar sudah melekat pada diri mereka masing-masing. Warga belajar hanya perlu melihatnya dari sudut pandang pengetahuan untuk membat mereka memahami bahwa apa yang mereka lakukan sebenarnya merupakan bagian dari pendidikan IPS. Sumber belajar IPS ynag luas 
juga membantu warga belajar untuk menemukan contoh dan perbandingan yang lebih banyak lagi ketika proses pembelajaran berlangsung sebab semua yang mereka jalani termasuk bagian dari pendidikan IPS.

Pada akhirnya warga belajar SPNF SKB Kab Banjar berhasil dengan penerapan pendidikan IPS dalam kehidupan sosial mereka walaupun tidak semuanya bisa berjalan dengan baik seperti yang diharapkan. Interaksi maupun hubungan sosial yang tidak berlangsung dengan baik juga bisa membantu warga belajar untuk belajar. Mereka bisa menyadari kesalahan yang ada pada proses sebelumnya dan melanjutkan proses lain lalu membuat hal tersebut berhasil. Bukan berarti pendidikan IPS yang bersumber dari masyarakat ini akan mudah mereka pahami, akan tetapi karena pendidikan IPS adalah pendidikan yang bertujuan untuk memberikan solusi dari masalah sosial mereka, pendidikan IPS adalah pendidikan yang tidak bisa dipisahkan dari kehidupan sosial masyarakat.

\section{SIMPULAN}

Kehidupan sosial warga belajar SPNF SKB bisa dilihat dari kehidupan dan hubungan-hubungan sosial yang mereka di lingkungan sekolah dan lingkungan keluarga. Kehidupan sosial warga belajar di lingkungan sekolah ini terjalin diantara sesama warga belajar, dengan para pengelola, serta dengan para tutor. Walaupun tidak setiap hari mereka bisa bertemu dan bertatap muka dengan para tutor, akan tetapi kehidupan sosial yang mereka jalin tetap terjaga dengan baik. Interaksi warga belajar dengan para tutor dan pengelola tidak hanya berjalan pada saat pembelajaran saja tetapi juga ketika berda di luar itu.

Kehidupan sosial warga belajar juga berjalan dengan baik ketika berada di lingkungan keluarga. Walaupun dalam prosesnya proses interaksi dan hubungan sosial tidak selalu berjalan dengan mulus, gambaran kehidupan sosial yang dijalani oleh warga belajar tidak sama sekali menunjukkan masalah. Hal ini terbukti dengan mampunya mereka untuk menunjukkan masalahmasalah dan juga solusi sosial di dalam proses pembelajaran. Hal ini berarti para warga beajar mampu untuk mengkomparasikan apa yang mereka jalani di lingkungan keluarga dan masyarakat ke dalam pembelajaran.

Implementasi pendidikan IPS ke dalam kehidupan sosial masyarakat warga belajar sudah tercermin di dalam gambaran keseharian mereka. Penerapan pendidikan IPS yang berjalan dengan baik ini tidak terlepas dari luas dan tidak terbatasnya sumber pembelajaran mereka. Penerapan yang berhasil ini tidak serta merta mencakup seluruh maksud dan tujuan dari pendidikan IPS itu sendiri. Artinya pendidikan IPS juga harus terus melakukan perkembangan dan pembaharuan demi teratasinya solusi yang akan memecahkan masalah-masalah sosial warga belajar lebih dari yang ada sekarang. Pembaharuan dan perkembangan dalam pendidikan IPS akan terus menurus terjadi dengan mempertimbangkan kemajuan dari kehidupan kita sekarang ini. Dengan demikian tujuan dan maksud dari pendidikan juga sedikit demi sedikit akan tercapai. 


\section{DAFTAR PUSTAKA}

Abbas, E. W. (2020). Menulis Artikel Jurnal Internasional. Progam Studi Pendidikan Ilmu PengetahuanSosial Jurusan Pendidikan Ilmu Pengetahuan Sosial Fakultas Keguruan dan Ilmu Pendidikan Universitas Lambung Mangkurat.

Abbas, E. W. (2015). Pendidikan IPS Berbasis Kearifan Lokal. WAHANA Jaya Abadi.

Abbas, E. W. (2013). Mewacanakan Pendidikan IPS. Mewacanakan Pendidikan IPS.

Anggraeni, A., \& Hendrizal, H. (2018). Pengaruh Penggunaan Gadget Terhadap Kehidupan Sosial Para Siswa Sma. Pelita Bangsa Pelestari Pancasila, 13(1), 64-76.

Chandra, Ika Mayasari. (2014). Pendidikan Karakter Dalam Pembelajaran Ips Di SMP Negeri 9 Banjarbaru. Jurnal Socius Vol 3 No.1

Indonesia, P. R. (2005). Peraturan Pemerintah Republik Indonesia nomor 19 tahun 2005 tentang standar nasional pendidikan. Departemen Pendidikan Nasional Republik Indonesia.

Hariyadi, Permatasari Melly Agustina. (2020). The Role of the Muhtadin Sabilal Mosque in the Social Life of Communities. The Kalimantan Social Studies Journal Vol. 1, (2).

Mulyono, Dinno. (2012). Menegaskan Karakter Pendidikan Non Formal. Jurnal Ilmiah Program Studi Pendidikan Luar Sekolah STKIP Siliwangi Bandung, Vol 1, No.1
Nursa'ban, M. (2007). Implementasi student centered learning berbasis internet dalam pembelajaran geografi program pendidikan non formal kejar paket C. Diklus, 6(11).

Peraturan Menteri Pendidikan dan Kebudayaan Republik Indonesia. (2013). Pendirian Pendidikan Satuan Non Formal. Jakarta

Putra, Muhammad Adhitya Hidayat. (2019) Building Character Education Through The Civilization Nations Children. The Kalimantan Socius Studies Journal Vol. 1 No. 1

Rahayu, A. S. (2017). Kehidupan Sosial Ekonomi Single Mother dalam ranah domestik dan publik. Jurnal Analisa Sosiologi, 6(1).

Surwiyanta, A. (2003). Dampak pengembangan pariwisata terhadap kehidupan sosial budaya dan ekonomi. Media wisata, 2(1).

Syaharuddin, Akhmad Munaya Rahman, Ridha Fitriyani. (2019). Utilization Of Social Community As Learning Resources On Social Studies. The Kalimantan Socius Studies Journal, Vol 1 No 1

Rosiana, Ananda. (2015). Pengaruh Pendidikan Lingkungan Hidup Dan Iklim Organisasi Sekolah Terhadap Motivasi Belajar Ips Siswa Smkn 1 Martapura. Jurnal Socius Vol 4 No. 2

Wahab, Abdul. 2008. Analisis Kebijaksanaan, Dari Formulasi Ke Implementasi Kebijaksanaan Negara. Jakarta: bumi aksara

Widodo, W., \& Soedjarwo, S. (2019, August). Analisis Kebutuhan Pendidikan Non Formal di Sekolah. 
In Prosiding Seminar Nasional \& Temu Kolegial Jurusan PLS Se Indonesia (pp. 21-25).
Zunaidi, M. (2013). Kehidupan Sosial Ekonomi Pedagang Di Pasar Tradisional Pasca Relokasi Dan Pembangunan Pasar Modern. Jurnal Sosiologi Islam, 3(1). 